\title{
Preparation of Anion Exchange Resin Loaded with Ferric Oxide for Arsenic (V) Removal from Aqueous Solution
}

\author{
Sujitra Tandorn, Orn-Anong Arqueropanyo, Wimol Naksata, and Ponlayuth Sooksamiti
}

\begin{abstract}
In this study, an adsorbent (FO-Dowex) was prepared by modification of commercial strong base anion exchange resin (Dowex marathon MSA) with ferric oxide (FO) and applied as adsorbent for removal of $\mathrm{As}(\mathrm{V})$ from aqueous solution. The effects of initial iron concentration and reaction contact time on adsorption capacity of $\operatorname{As}(V)$ were investigated for optimal conditions of adsorbent. In addition, the FO-Dowex was characterized using scanning electron microscopy and Fourier transformed infrared spectroscopy. It was shown that the optimal initial iron concentration and reaction contact time were $0.5 \mathrm{~mol} / \mathrm{L}$ and $12 \mathrm{~h}$, respectively. Comparison of adsorption performance between the prepared FO-Dowex and the anion resin revealed that FO-Dowex exhibited higher adsorption capacity with the value of $74.07 \mathrm{mg} / \mathrm{g}$ compared to the one from anion resin $(49.75 \mathrm{mg} / \mathrm{g})$ under the same conditions. It can be suggested that the modification of anion resin with ferric oxide can significantly improve the adsorption performance in $\operatorname{As}(V)$ removal.
\end{abstract}

Index Terms-Adsorption, arsenic, ferric oxide, anion exchange resin.

\section{INTRODUCTION}

Arsenic pollution has become a serious concern in many countries throughout the world due to its high toxicity and adverse effect on human health and environment. Arsenic can be released into environment through the natural process and human activities [1]. Long-term uptake of high concentration of arsenic can cause several health effects such as skin hyperpigmentation, cardiovascular disease and various types of cancer. As a result, World Health Organization (WHO) has established the maximum contaminant limit (MCL) of 10 $\mu \mathrm{g} / \mathrm{L}$ [2]. Several techniques have been applied for removal of arsenic from water including oxidation, precipitation, coagulation, adsorption, ion-exchange, and membrane filtration. Among them, adsorption is an economical and effective method for arsenic removal [3]. Ion exchange resin is an effective adsorbent for removal of arsenic from water. However, it exhibited low selectivity in the presence of other competing anions such as chloride, sulfate, and nitrate leading to the low adsorption

Manuscript received October 4, 2016; revised January 25, 2017. This work was supported in part by the Development and Promotion of Science and Technology Talents Project (DPST scholarship), Thailand.

Sujitra Tandorn and Wimol Naksata are with the Department of Chemistry, Faculty of Science, Chiang Mai University, Thailand (e-mail: tandorn.sujitra@gmail.com, scchi021@chiangmai.ac.th).

Orn-Anong Arqueropanyo is with the Department of Chemistry and Materials Science Research Center, Faculty of Science, Chiang Mai University, Thailand (e-mail: orn.arquero@gmail.com).

Ponlayuth Sooksamiti is with the Department of Primary Industry and Mine Office Region3, Chiang Mai, Thailand (e-mail: sooksamiti@hotmail.com). performance of ion exchange resin [4]. Therefore, it is essential to develop a new selective adsorbent for arsenic removal. In recent years, polymeric-based ferric oxide adsorbents have become more attractive for the environmental remediation. These materials combined the advantages of both excellent mechanical properties of polymeric ion exchange and the specific affinity of ferric oxide toward target pollutant [5]. Previous studies have shown that fabrication of these hybrid adsorbents by dispersing or loading of iron oxide onto polymeric ion exchange can provide high efficiency for removal of toxic pollutants, including arsenic, phosphate, selenium, and antimony [6]-[9]. However, Hristovski et al. [10] suggested that the preparation condition was the important factor that significantly influenced on the formation of iron oxide nanoparticle and the adsorption capacity of adsorbent. Until now, little is known about the effect of preparation conditions on the adsorption performance of adsorbent, and thus further investigations are required.

Here, the effects of iron concentration and reaction contact time on the adsorption capacity of resulting adsorbent for $\mathrm{As}(\mathrm{V})$ were investigated and the optimal conditions for adsorbent preparation were determined. The prepared adsorbent (FO-Dowex) was also characterized by scanning electron microscopy (SEM), energy dispersive X-ray spectroscopy (EDX), and Fourier transform infrared spectroscopy (FTIR) techniques. In addition, the adsorption performance of $\mathrm{As}(\mathrm{V})$ by FO-Dowex and host anion resin were compared. The influence of iron modification on the adsorption capacity was also discussed.

\section{MATERIAL AND METHOD}

\section{A. Materials}

Dowex marathon MSA was purchased from Aldrich-Sigma, USA which was used as a starting material for preparation of adsorbent. It is a strong base anion exchange resin which consists of positive charge of quaternary ammonium functional group and polystyrene-divinylbenzene matrix. The diameter of resin beads varied between 560-600 $\mu \mathrm{m}$.

\section{B. Chemicals}

All reagents used in this study were analytical grade. Ferric chloride $\left(\mathrm{FeCl}_{3} \cdot 6 \mathrm{H}_{2} \mathrm{O}\right)$ was purchased from Loba Chemie Pvt. Ltd., India. Sodium arsenate $\left(\mathrm{Na}_{2} \mathrm{HAsO}_{4} \cdot 7 \mathrm{H}_{2} \mathrm{O}\right)$ was supplied by Aldrich-Sigma, USA. Sodium chloride $(\mathrm{NaCl})$ and sodium hydroxide $(\mathrm{NaOH})$ were obtained from Thermo Fisher, Australia. Stock solution of As(V) (1000 mg/L) was prepared by dissolving desired amount of $\mathrm{Na}_{2} \mathrm{HAsO}_{4} \cdot 7 \mathrm{H}_{2} \mathrm{O}$ 
in deionized water.

\section{Preparation of Adsorbent (FO-Dowex)}

The adsorbents were prepared by ion-exchange deposition technique. The preparation procedure was performed according to the method in literature [7]. In details, $5 \mathrm{~g}$ of Dowex anion resin was added to the mixture of $\mathrm{FeCl}_{3}-\mathrm{HCl}$ solution containing different concentration of $\mathrm{FeCl}_{3}$ $(0.025-3 \mathrm{M})$ and the mixtures were stirred at various time intervals (2-24 hours) and filtered. In this step, the optimum preparation conditions such as initial iron concentration and reaction contact time were investigated. After that, the anion resins were filtered and soaked in $1 \mathrm{M} \mathrm{NaOH}-\mathrm{NaCl}$ solution. The mixtures were stirred for $12 \mathrm{~h}$ at room temperature and filtered. Then, the solid particles were washed with deionized water and ethanol solution to remove unloaded iron oxide and dried at $55^{\circ} \mathrm{C}$ for $24 \mathrm{~h}$. Finally, the obtained adsorbents were kept in vacuum desiccator for further use.

\section{Characterization of Adsorbents}

Various techniques have been used to determine the physical and chemical properties of Dowex anion resin and FO-Dowex. Fourier transform infrared spectrophotometer (FTIR; Tensor 27, Bruker) was used to investigate the surface functional groups in the wavenumber range of $400-4000 \mathrm{~cm}^{-1}$. In addition, the specific surface and pore volumes were determined by the $\mathrm{N}_{2}$ adsorption and desorption method at $77 \mathrm{~K}$ using Quantachrome autosorb 1MP. Moreover, the surface morphology and elemental compositions of adsorbents before and after loading of ferric oxide were examined using scanning electron microscope (SEM; JOEL, model JSM-5910) and energy dispersive X-ray spectroscopy (EDX), respectively.

\section{E. Adsorption Experiment}

The experiments were carried out in batch system by mixing fixed amount of adsorbent with $100 \mathrm{ml}$ of $\mathrm{As}(\mathrm{V})$ solution in Erlenmeyer flask. The initial $\mathrm{pH}$ was adjusted to desirable $\mathrm{pH}$ value using $0.1 \mathrm{M} \mathrm{NaOH}$ or $0.1 \mathrm{M} \mathrm{HCl}$. The mixture was shaken in a water bath shaker (model WSB-45, Daihan scientific, Korea) at constant speed of $100 \mathrm{rpm}$. After adsorption time, the solution was filtered through whatman No.1 filter paper and the concentration of arsenic in filtrate was analyzed by inductively coupled plasma emission spectrometer (ICP-OES; Optima3000, Perkin Elmer, USA) The amount of $\mathrm{As}(\mathrm{V})$ adsorbed at equilibrium $\left(\mathrm{q}_{\mathrm{e}}\right)$ was calculated by the following equation:

$$
q_{e}=\frac{\left(C_{0}-C_{e}\right) V}{\mathrm{~W}}
$$

where $C_{0}$ and $C_{e}$ are the initial and equilibrium $\mathrm{As}(\mathrm{V})$ concentration $(\mathrm{mg} / \mathrm{L})$, respectively, $V$ is the volume of $\mathrm{As}(\mathrm{V})$ solution $(\mathrm{L})$ and $\mathrm{W}$ is amount of $\operatorname{adsorbent}(\mathrm{g})$

To study the effects of initial iron concentration and reaction time on $\mathrm{As}(\mathrm{V})$ adsorption, the experiments were conducted with initial As(V) concentration of $30 \mathrm{mg} / \mathrm{L}$ and $0.05 \mathrm{~g}$ of adsorbent prepared under various conditions. The mixtures were shaken at $30^{\circ} \mathrm{C}$ for $6 \mathrm{~h}$ and the remaining $\mathrm{As}(\mathrm{V})$ concentration was determined by ICP-OES. The optimum preparation conditions were evaluated by comparing the adsorption performance of absorbent obtained from different conditions.

\section{F. Adsorption Isotherm}

In order to determine the adsorption capacity of adsorbent, the experiments were conducted with six different initial $\mathrm{As}(\mathrm{V})$ concentrations ranging from 10 to $60 \mathrm{mg} / \mathrm{L}$ at constant temperature of $30^{\circ} \mathrm{C}$, the contact time of $6 \mathrm{~h}$, and the initial $\mathrm{pH}$ was controlled at $\mathrm{pH}=5$. Langmuir and Freundlich isotherms were used to analyzed the experimental adsorption data of $\mathrm{As}(\mathrm{V})$ onto FO-Dowex and anion resin.

Langmuir isotherm is based on monolayer adsorption on the active sites of adsorbent with a finite number of identical binding sites [11], [12]. The linear form of Langmuir isotherm is given by

$$
\frac{C_{e}}{q_{e}}=\frac{C_{e}}{q_{m}}+\frac{1}{q_{m} b}
$$

where $q_{e}$ is the amount of $\mathrm{As}(\mathrm{V})$ adsorbed at equilibrium $(\mathrm{mg} / \mathrm{g}), \quad C_{e}$ is the equilibrium $\mathrm{As}(\mathrm{V})$ concentration $(\mathrm{mg} / \mathrm{L}), q_{m}$ and $\mathrm{b}$ are Langmuir constants which represent the maximum adsorption capacity $(\mathrm{mg} / \mathrm{g})$ and the energy of adsorption, respectively. These parameters are determined from the slope and intercept of the linear plot of $C_{e} / q_{e}$ and $C_{e}$.

Freundlich adsorption isotherm can be applied for multilayer adsorption on heterogeneous surface with non-uniform distribution of adsorption heat [11], [12]. The linearity of Freundlich isotherm can be expressed by the following equation

$$
\log q_{e}=\frac{1}{n} \log C_{e}+\log K_{f}
$$

where $K_{f}$ and $\mathrm{n}$ are Freundlich constants associated with capacity and intensity of adsorption, respectively. The Freundlich isotherm parameters are obtained by fitting the curve of $\log q_{e}$ versus $\log C_{e}$.

\section{RESULTS AND DISCUSSION}

\section{A. Characterization of Adsorbents}

As shown in Fig. 1, the original anion resin was light yellow spherical beads whereas the prepared adsorbent (FO-Dowex) was brown color. However, the material kept its original spherical shape after loading with ferric oxide. The SEM image of Dowex anion resin (Fig. 2a) showed the uniform and smooth surface, while the surface of FO-Dowex (Fig. 2b) was rough due to the deposition of iron oxide particles. The EDX analysis of anion resin and FO-Dowex are illustrated in Fig. 3a and Fig. 3b, respectively. It can be revealed that Dowex anion resin contained mainly of carbon and chlorine which may result from the polymeric matrix and exchangeable ion of anion resin composition. Meanwhile, $\mathrm{Fe}$ element (53.24\%wt) was detected in the element compositions of FO-Dowex. This confirmed that the loading 
of iron oxide onto anion resin is successful. Fig. 4 illustrated the FTIR spectra of adsorbent before and after loading of ferric oxide. The FTIR spectrum of anion resin (Fig. 4a) exhibited a broad peak at $3428 \mathrm{~cm}^{-1}$, which can be assigned to O-H stretching vibration of hydroxyl group [13], [14]. Meanwhile, three peaks at about 3015, 2924 and $2824 \mathrm{~cm}^{-1}$ indicate $\mathrm{C}-\mathrm{H}$ stretching of aromatic ring of polystyrene-divinylbenzne matrix in anion resin [14]. Furthermore, a significant peak at $1481 \mathrm{~cm}^{-1}$ corresponds to $\mathrm{C}-\mathrm{H}$ bending of quaternary ammonium functional group of anion resin [15]. As shown in Fig. 4b, the peak pattern of FO-Dowex is similar to that of anion resin. However, an additional peak observed at $581 \mathrm{~cm}^{-1}$ was attributed to $\mathrm{Fe}-\mathrm{O}$ stretching vibration which clearly indicated the presence of loaded ferric oxide onto anion resin [16].

The data in Table I clearly showed that the specific surface area of FO-Dowex $(21.62 \mathrm{~m} 2 / \mathrm{g})$ was higher than that of the anion resin $(17.13 \mathrm{~m} 2 / \mathrm{g})$, owing to the high surface to mass ratio of iron oxide particle [17]. However, the pore volume of FO-Dowex turns out to be slightly lower than that of anion resin (see Table I). This observation may be attributed by the pore blockage caused by iron oxide loading, which might reduce the porosity of adsorbent [18].
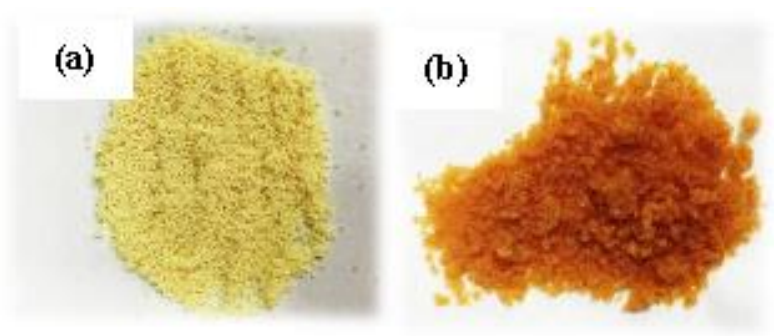

Fig. 1. Photographs of (a) Dowex anion resin (b) FO-Dowex.

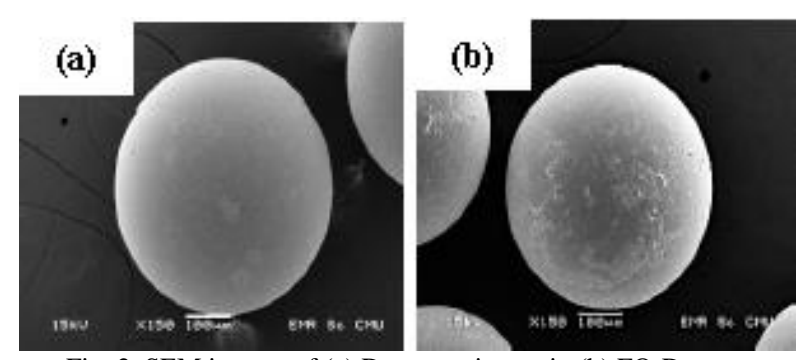

Fig. 2. SEM images of (a) Dowex anion resin (b) FO-Dowex.

TABLE I: SPECIFIC SURFACE AREA AND POROSITY OF THE ADSORBENTS IN THIS STUDY

\begin{tabular}{lll}
\hline \hline Adsorbent & BET surface area $\left(\mathrm{m}^{2} / \mathrm{g}\right)$ & Pore volume $\left(\mathrm{cm}^{3} / \mathrm{g}\right)$ \\
\hline Dowex anion resin & 17.13 & 0.0273 \\
FO-Dowex & 21.62 & 0.0256 \\
\hline \hline
\end{tabular}

\section{B. Optimization for Adsorbent Preparation}

In this part, the optimal conditions for $\mathrm{As}(\mathrm{V})$ adsorption on FO-Dowex adsorbents were evaluated by varying initial iron concentration and reaction contact time. As shown in Fig. 5, the adsorption capacity increased with increasing of $\mathrm{FeCl}_{3}$ concentration from 0.025 to $0.5 \mathrm{~mol} / \mathrm{L}$. This observation may be attributed by the higher amount of adsorption sites onto anion resin surface, resulting in an enhancement of the As(V) adsorption. The maximum adsorption capacity was obtained at $0.5 \mathrm{~mol} / \mathrm{L}$ of $\mathrm{FeCl}_{3}$. However, a further increase of iron concentration up to $3 \mathrm{~mol} / \mathrm{L}$ resulted in a drop of the adsorption capacity. It is probably due to the pore blockage and self-aggregation of iron oxide particle at a high amount of iron. This may reduce the available active sites for adsorption and hinder the diffusion of $\mathrm{As}(\mathrm{V})$ into the adsorption sites of adsorbent, lowering the adsorption capacity [19], [20].
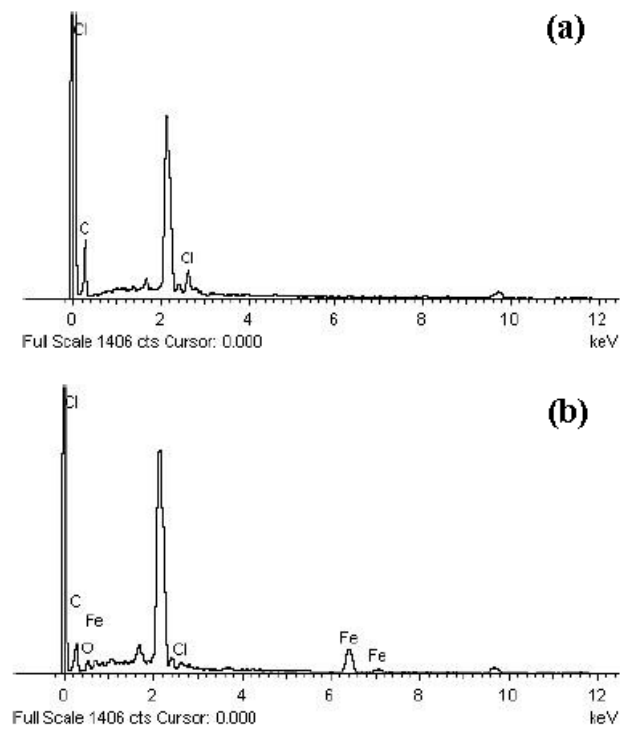

Fig. 3. EDX analysis of (a) Dowex anion resin (b) FO-Dowex.

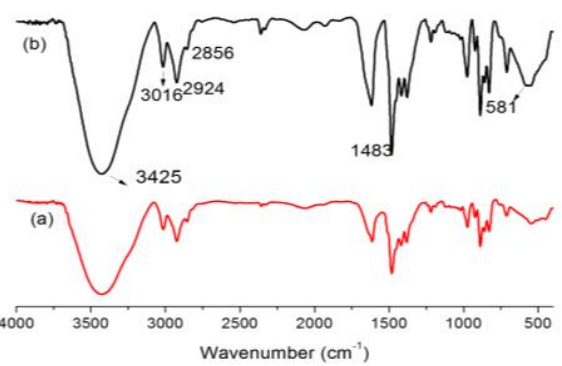

Fig. 4. FTIR spectra of (a) Dowex anion resin (b) FO-Dowex.

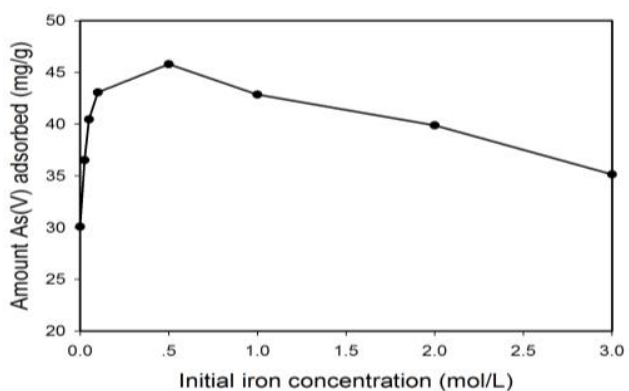

Fig. 5. Effect of initial iron(III) concentration on $\mathrm{As}(\mathrm{V})$ adsorption capacity.

To find an optimum reaction contact time, anion resins were added into iron solution and stirred at various time intervals between 2 to $24 \mathrm{~h}$, as illustrated in Fig. 6 . The results reveal that the adsorption capacity increased from 32.78 $\mathrm{mg} / \mathrm{g}$ to $45.69 \mathrm{mg} / \mathrm{g}$ when increasing of the contact time from 2 to $12 \mathrm{~h}$. For a longer reaction time, it provided more times for iron to react with quaternary ammonium functional group of anion resin through ion-exchange process. This also increases opportunity for iron oxide pre-loading onto anion resin before precipitation with alkaline solution [9]. However, more contact time (after $12 \mathrm{~h}$ ) did not significantly affect the $\mathrm{As}(\mathrm{V})$ adsorption capacity. 


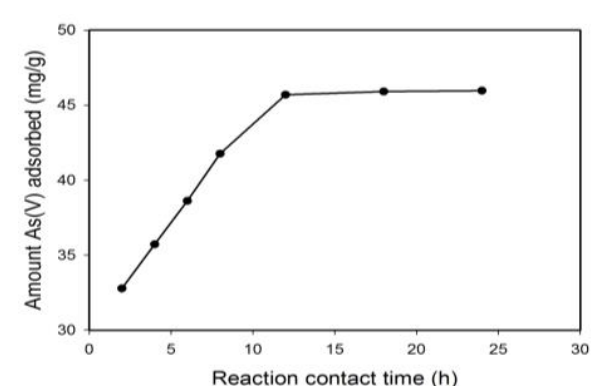

Fig. 6. Effect of reaction contact time on the adsorption capacity of $\mathrm{As}(\mathrm{V})$.

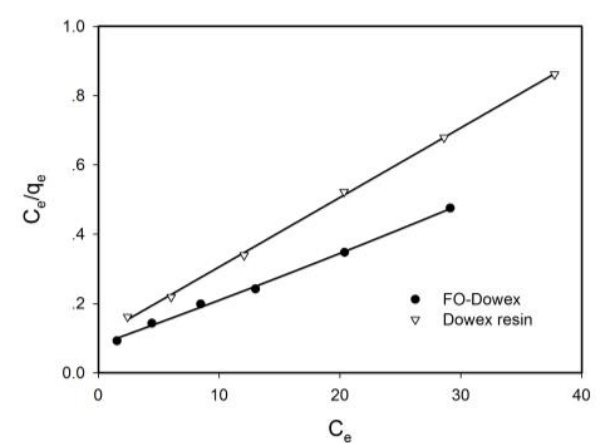

(a)

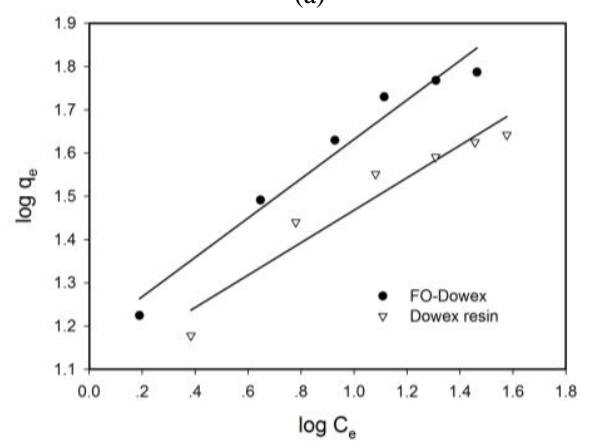

(b)

Fig. 7. (a) Langmuir and (b) Freundlich adsorption isotherm plots of $\mathrm{As}(\mathrm{V})$ adsorption onto Dowex anion resin and FO-Dowex.

From the results, the optimum conditions for adsorbent preparation were obtained with $0.5 \mathrm{~mol} / \mathrm{L}$ of iron concentration and a contact time of $12 \mathrm{~h}$. These conditions were further applied for further adsorption discussed below.

\section{Adsorption Isotherm}

The linear plots of Langmuir and Freundlich isotherm for $\mathrm{As}(\mathrm{V})$ adsorption onto FO-Dowex and Dowex anion resin are shown in Fig. 7a and 7b, respectively. The Langmuir and Freundlich isotherm parameters along with correlation coefficient value $\left(\mathrm{R}^{2}\right)$ are summarized in Table II. According to the $\mathrm{R}^{2}$ values, the Langmuir isotherm model fit quite well $\left(\mathrm{R}^{2}>0.99\right)$ with the experimental data for both FO-Dowex and anion resin, indicating the monolayer adsorption on homogenous surface. According to Langmuir isotherm, the maximum adsorption capacities $\left(\mathrm{q}_{\mathrm{m}}\right)$ of FO-Dowex and anion resin were 74.07 and $49.75 \mathrm{mg} / \mathrm{g}$, respectively. The higher adsorption capacity of FO-Dowex was attributed to the increase of surface area resulting from the presence of iron oxide and this may provide more adsorption sites on the adsorbent surface for As(V) adsorption [17], [18]. Also, the formation of inner sphere complex between ferric oxide and As(V) would increase the adsorption affinity [21], [22]. Moreover, the addition of $\mathrm{Fe}$ may increase the positive charges on the adsorbent surface leading to the enhanced electrostatic interaction between arsenate and iron oxide [23]. Therefore, it can be indicated that the loading of iron oxide is an important factor for enhancement of the adsorption capacity of anion resin for As(V). For Freundlich isotherm, the $\mathrm{K}_{\mathrm{f}}$ constant calculated for FO-Dowex (15.02) was higher than that for Dowex anion resin (12.37). In addition, the values of parameter " $n$ " obtained in this study were greater than unity for both adsorbents, indicating that adsorption of $\mathrm{As}(\mathrm{V})$ on both FO-Dowex and anion resin were favorable. Comparison of adsorption capacity of different adsorbents to the values reported in literature for $\mathrm{As}(\mathrm{V})$ removal are presented in Table III. Overall, the data clearly indicates that FO-Dowex exhibits higher adsorption capacity than other iron-coated adsorbents.

TABLE II: ISOTHERM PARAMETERS FOR AS(V) ADSORPTION ONTO DOWEX ANION RESIN AND FO-DOWEX

\begin{tabular}{llll}
\hline \hline $\begin{array}{l}\text { Isotherm } \\
\text { model }\end{array}$ & Parameter & FO-Dowex & Anion resin \\
\hline Langmuir & $\mathrm{q}_{\mathrm{m}}$ & 74.07 & 49.75 \\
& $\mathrm{~b}$ & 0.18 & 0.19 \\
& $\mathrm{R}^{2}$ & 0.9972 & 0.9993 \\
Freundlich & $\mathrm{K}_{\mathrm{f}}$ & 15.02 & 12.37 \\
& $\mathrm{n}$ & 2.20 & 2.67 \\
& $\mathrm{R}^{2}$ & 0.9651 & 0.9250 \\
\hline \hline
\end{tabular}

TABLE III: COMPARISON OF MAXIMUM ADSORPTION CAPACITIES OF VARIOUS IRON-BASED ADSORBENTS FOR AS(V) REMOVAL

\begin{tabular}{lll}
\hline \hline Adsorbent & $\begin{array}{l}\mathrm{q}_{\mathrm{m}} \\
(\mathrm{mg} / \mathrm{g})\end{array}$ & References \\
\hline Iron coated diatomite & 8.6 & {$[24]$} \\
Iron coated chitosan & 35.7 & {$[25]$} \\
Bead cellulose loaded with iron oxyhydroxide & 33.2 & {$[26]$} \\
Iron coated rice husk & 2.5 & {$[27]$} \\
Iron coated mesoporous carbon & 5.15 & {$[28]$} \\
FO-Dowex & $\mathbf{7 4 . 0 7}$ & This study \\
\hline \hline
\end{tabular}

\section{CONCLUSION}

In this study, FO-Dowex was successfully prepared by loading of iron oxide onto anion resin through ion-exchange deposition method using $\mathrm{FeCl}_{3}$ as the precursor. The presence of ferric oxide loaded on anion resin was confirmed by FTIR and EDX analysis. The results showed that both the initial iron concentration and the reaction contact time have a significant effect on As(V) adsorption capacity. The optimal conditions were obtained with the iron concentration of 0.5 $\mathrm{mol} / \mathrm{L}$ and the reaction contact time of $12 \mathrm{~h}$. Under the optimal conditions, the FO-Dowex exhibits a remarkably increased adsorption capacity as compared to the case of anion resin. The equilibrium adsorption data for both FO-Dowex and anion resin fitted well to the Langmuir isotherm model. Based on the results, it can be suggested that FO-Dowex would serve as a potential adsorbent for removal of arsenic from aqueous solution.

\section{ACKNOWLEDGMENT}

The work was financially supported by the Development and Promotion of Science and Technology Talents Project (DPST scholarship), Thailand. The authors would like to give special thanks to Department of Chemistry and 
Materials Science Research Center, Faculty of Science, Chiang Mai University, and Department of Primary Industry and Mine Office Region 3, Chiang Mai for instruments support along this study.

\section{REFERENCES}

[1] M. J. Demarco, A. K. Sengupta, and J. E. Greenleaf, "Arsenic removal using a polymeric/inorganic hybrid sorbent," Water Res., vol. 37, pp. 164-176, 2003

[2] M. H. Stanic, B. Kalajdzic, M. Kules, and N. Velic, "Arsenite and arsenate sorption by hydrous ferric oxide/polymeric material," Desalination, vol. 229, pp. 1-9, 2008.

[3] I. A. Katsoyiannis and A. I. Zouboulis, "Removal of arsenic from contaminated water sources by sorption onto iron-coated polymeric materials," Water Res., vol. 36, pp. 5141-5155, 2002.

[4] P. Sylvester, P. Westerhoff, T. Moller, M. Badruzzaman, and O. Boyd, "A hybrid sorbent utilizing nanoparticles of hydrous iron oxide for arsenic removal from drinking water," Environ. Eng. Sci., vol. 24, pp. 104-112, 2007

[5] B. J. Pan, B. Pan, W. Zhang, L. Lv, Q. X. Zhang, and S. Zheng, "Development of polymeric and polymer-based hybrid adsorbents for pollutants removal from water," Chem. Eng. J., vol. 151, pp. 19-29, 2009.

[6] L. Cumbal and A. K. Sengupta, "Arsenic removal using polymer-supported hydrated iron(III) oxide nanoparticles: role of donnan membrane effect," Chem. Eng. J., vol. 151, pp. 19-29, 2009.

[7] B. J. Pan, J. Wu, B. Pan, L. Lv, W. M. Zhang, L. Xiao, X. S. Wang, X. C. Tao, and S. R. Zheng, "Development of polymer-based nanosized hydrated ferric oxides(HFOs) for enhanced phosphaste removal from waste effluents," Water Res., vol. 43, pp. 4421-4429, 2009.

[8] B. J. Pan, L. Xiao, G. Nie, B. C. Pan, J. Wu, L. Lv, W. M. Zhang, and S. R. Zheng, "Adsorptive selenite removal from water using a nano-hydrated ferric oxides(HFOs)/polymer hybrid adsorbent," $J$. environ. Monit., vol. 12, pp. 305-310, 2010

[9] Y. Y. Miao, F. C. Han, B. C. Pan, Y. J. Niu, G. Nie, and L. Lv, "Antimony(V) removal from water by hydrated ferric oxide supported by calcite sand and polymeric anion exchanger," J. environ. Sci., vol. 26, pp. 307-314, 2013.

[10] K. D. Hristovski, F. K. Westerhoff, T. Moller, and P. Sylvester, "Effect of synthesis conditions on nano-iron(hydr)oxide impregnated granulated activated carbon," Chem. Eng. J., vol. 146, pp. 237-243, 2009.

[11] K. Y. Foo and B. H. Hameed, "Insights into the modelling of adsorption isotherm systems," Chem. Eng. J., vol. 156, pp. 2-10, 2010.

[12] S. Agarry and O. Gunleye, "Chemically treated kola nut pod as low-cost natural adsorbent for the removal of 2, 4-dinitrophenol from synthetic wastewater: batch equilibrium, kinetic, and thermodynamic modelling studies" Turkish J Eng. Env. Sci., vol. 38, pp. 11-40, 2014.

[13] D. Kauspediene, E. Kazlauskiene, R. Cesuniene, A. Gefeniene, R. Ragauskas, and A. Selskiene, "Removal of the phatalocynaine dye from acidic solutions using resin with the polystyrene divinylbenzne matrix," Chemija, vol. 24, pp. 171-181, 2013.

[14] S. Ghosh, K. J. Dhole, M. K. Tripathy, R. Kumar, and R. S. Sharma, "FTIR spectroscopy in the characterization of the mixture of nuclear grade cation and anion exchange resins," J. Radioanal. Nucl. Chem., vol. 304, pp. 917-923, 2015.

[15] S. M. Alshehri, M. Naushad, T. Ahamad, Z. A. Alothman, and A. Aldalbahi, "Synthesis, characterization of curcumin based ecofriendly antimicrobial bio-adsorbent for the removal of phenol from aqueous medium," Chem. Eng. J.., vol. 254, pp. 181-189, 2014.

[16] Q. Zhou, X. Wang, J. Y. Liu, and L. Zhang, "Phosphorus removal from wastewater using nano-particulates of hydrated ferric oxide doped activated carbon fiber prepared by sol-gel method," Chem. Eng. J.., vol 200, pp. 619-626, 2012.

[17] S. Dixit and J. G. Hering, "Comparison of Arsenic(V) and arsenic(III) sorption onto iron oxide minerals: implications for arsenic mobility," Environ. Sci. Technol., vol. 39, pp. 3833-3943, 2005

[18] Z. Gu, J. Fang, and B. Deng, "Preparation and evaluation of GAC-based iron-containing adsorbent for arsenic removal," Environ. Sci. Technol., vol. 39, pp. 3833-3943, 2005.

[19] J. T. Mayo, C. Yuvuz, S. Yean, L. Cong, H. Shipley, W. Yu, J. Falkner, A. Kan, M. Tomson, and V. L. Colvine, "The effect of nanocrystalline magnetite size on arsenic removal," Sci. Technol. Adv. Mater., vol. 8, pp. 71-75, 2007.
[20] N. Zhang, L. S. Lin, and D. Gang, "Adsorptive selenite removal from water using iron-coated GAC adsorbents," Water Res., vol. 42, pp. 3809-3816, 2008.

[21] H. Zeng, B. Fisher, and D. E. Giammar, "Individual and competitive adsorption of arsenate and phosphate to a high-surface iron oxide-based sorbent," Environ. Sci. Technol., vol. 42, pp. 147-152, 2008.

[22] G. Lefevere, "In situ Fourier-transform infrared spectroscopy studies of inorganic ions adsorption on metal oxide and hydroxides," $A d v$. Colloid and interface Sci., vol. 107, pp. 109-123, 2004.

[23] P. Longanathan, S. Vigneswaran, and J. Kandasamy, "Enhanced removal of nitrate from water using surface modification of adsorbents-A review," Environ. Manage., vol. 131, pp. 363-374, 2013

[24] Y. E. Pan, C. T. Chious, and T. F. Lin, "Adsorption of arsenic(V) by iron-oxide coated diatomite(IOCD)," Environ. Sci. Pollut. Res., vol. 17, pp. 1401-1410, 2010.

[25] J. Wang, W. H. Xu, L. Chen, X. J. Huang, and J. H. Liu, "Preparation and evaluation of magnetitle nanoparticles impregnated chitosan beads for arsenic removal from water," Chem. Eng. J., vol. 251, pp. 25-34 2014.

[26] X. J. Guo and F. Chen, "Removal of arsenic by bead cellulose loaded with iron oxyhydroxide from groundwater" Environ. Sci. Technol., vol. 39 , pp. 6808-6818, 2005

[27] E. Pehlivan, T. H. Tran, W. K. I. Ouedraogo, C. Schmidt, D. Zachmann and M. Bahadir, "Removal of $\mathrm{As}(\mathrm{V})$ from aqueous solutions by iron coated rice husk" Fuel Process. Technol., vol. 106, pp. 511-517, 2013

[28] G. Zhimang and D. Bolin, "Use of iron-containing mesoporous carbon(IMC) for arsenic removal from drinking water" Environ. Eng. Sci., vol. 24, pp. 112-113, 2007.

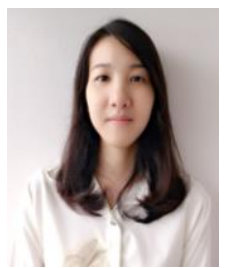

Sujitra Tandorn was born in Chiang Mai, Thailand on September 6, 1986. She received her B.Sc degree and M.Sc. degree in the field of chemistry from Chiang Mai University, Chiang Mai, Thailand in 2008 and 2011, respectively. In 2008 she worked the research about the adsorption of methylene blue from aqueous solution by using heated-treated leonardite as adsorbent. She is now studying for her $\mathrm{Ph}$. D. degree at Chiang Mai University, Chiang Mai, Thailand. Her research interests focus on adsorption, wastewater treatment and surface chemistry.

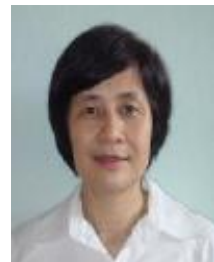

Orn-Anong Arqueropanyo was born in Chiang Mai, Thailand in 1952. She received her B.Sc degree in chemistry from Chiang Mai University, Chiang Mai, Thailand. From 1976-1980, she earned Ph.D (Physical Chemistry) degree from Bradford University, Bradford, UK.

From 1985-1987, she attained international seminar for research and study in chemical engineering technology and physical chemistry at the Universität Karlsruhe, DAAD, Federal Republic of Germany, for 18 months In 2004, she visited the Melbourne University, Melbourne, Australia. She had worked as lecturer in the Department of Chemistry, Chiang Mai University, Chiang Mai, Thailand until 2013.

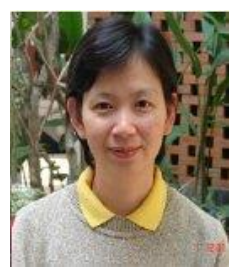

Wimol Naksata received her Ph.D (chemistry) degree from Chiang Mai University, Chiang Mai, Thailand in 1999. Her current research fields are polymer chemistry and pulp and paper chemistry. She is currently as lecturer in the Department of Chemistry, Chiang Mai University, Chiang Mai, Thailand. Assist. Prof. Dr. Arqueropanyo's research interests are in adsorption, neutron activation analysis and X-Ray flurescence and environmental study. She is an author of Surface Chemistry (published in Faculty of Science, Chiang Mai University, 1994).

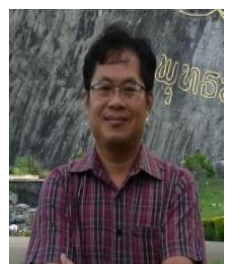

Ponlayuth Sooksamiti was born in Chiang Mai Province. He received his $\mathrm{Ph} . \mathrm{D}$. in analytical chemistry from Chiang Mai University, Chiang Mai, Thailand. $\mathrm{He}$ is working as expert environmental chemist at Office of Primary Industrial and Mines, Region 3 Chiang Mai, Thailand. His areas of interest are mine environmental risk assessment and mineral analysis.

Dr. Sooksamiti has many articles published in journal of Talanta, Analytical Sciences, Environmental Earth Sciences and Korean Journal of Chemical Engineering. 